\title{
A volta de Siracusa: a negação platônica
}

\author{
Henning Teschke
}

A exceção possui condições: o milagre pressupôs a regra, a qual torna visível no momento da sua suspensão. A compreensão da origem da filosofia relacionada ao "milagre grego", incluindo o empréstimo oriental, exige uma análise sóbria do seu advento para não se perder o entusiasmo. Com o pensamento filosófico emerge um novo tipo de saber que coincide com a interrupção do sacro validado pela narrativa mitológica. A religião procede por figuras e acontecimentos transcendentes que trazem consigo um plano hierárquico e projetivo. Daí deriva a proximidade do poema com a autoridade religiosa, e daí a criação dos deuses gregos mediante a poesia mitológica de Homero e Hesíodo. O ambíguo genérico da forma poética deixa intacta a aliança do discurso e do sacro reforçando o poder da origem. A filosofia, contudo, se inicia com a dessacralização da origem. As forças constitutivas do cosmos são entendidas por meio de exemplos dos fenômenos cotidianos. No início a natureza não foi diferente do que é hoje, pois desde sempre o fogo seca uma camisa úmida com a mesma velocidade. Os deuses olímpicos não são melhores que os mortais; a banalidade tranquilizante do dia a dia divino repleto de roubos, sequestros, assassinatos e vaidades se revela como mera reduplicação da vida humana. Só a conexão das razões e dos efeitos, a secularização argumentativa, destitui o prestígio religioso, desvalida o arcano mitológico, dessacraliza a autoridade. Nessa genealogia do logos, Platão marca a intervenção decisiva. A inversão dos critérios do saber válido elimina o mito dos procedimentos para atingir a verdade a fim de estabelecer um campo epistemológico conforme a verdade superior do logos. 
A relação entre mito e logos não apresenta simplesmente uma sucessão cronológica nem uma oposição lógica. Parmênides, Platão e Aristóteles marcam as três respostas possíveis a esse problema (BADIOU, 2008, p. 38), rememorando mais uma vez que o progresso não constitui uma categoria filosófica. O poema didático Da natureza de Parmênides demonstra no nível conceitual a existência inalterável do ser e a impossibilidade do nãoser. Mas o léxico ontológico se cruza com aquele da revelação divina apesar da depuração do relato dos elementos de fé que a envolvem. Na linguagem da salvação espiritual se realizam as núpcias da filosofia, da religião e da poesia. O proscênio pré-socrático da indistinção dos discursos resulta tanto na rivalidade híbrida quanto na fusão desses três. A imagem, a figura literária, a equivocidade da narração colaboram para possibilitar a univocidade da verdade. Já que não existem segundas núpcias nem divórcio definitivo da filosofia e da poesia, apenas restava a redefinição prosaica, a retomada desauratizada dos assuntos mais íntimos do casal envelhecido, caracterizado sempre mais por suas brigas. Nisso consistia a tarefa de Aristóteles, organizando a inclusão do saber do poema dentro da filosofia, ato nada dramático, mas, em contrapartida, administrativo. A poesia será abordada no quadro das definições e classificações, cercada por descrições e prescrições, delimitada na topologia epistemológica e reduzida a ser nada mais que uma província da filosofia cujo nome será estética. Entre o primeiro e terceiro passo se coloca o lançamento platônico. O legado sem partilha de Parmênides a Platão foram dois pretendentes cujas reivindicações se incluíram no mesmo domínio. Aristóteles, por sua parte, recebeu do seu mestre uma herança consideravelmente alterada: dois pretendentes cujas reivindicações se excluíram sendo coagidos a dividir o mesmo domínio. Platão criou as coordenações futuras da metafísica, o ser e o aparecer, em cima e embaixo, dentro e fora, verdadeiro e falso, ascensão e queda. Para isso, soube inventar cronotopoi conceituais e alegóricos que as sustentaram. Entretanto, parece mais fácil erguer uma distinção do que observá-la, mais difícil respeitar uma fronteira do que traçá-la. Apesar de todas as operações platônicas que insistem em abnegar a isomorfia perigosa do poder da categoria e do poder imaginário, a obra platônica é percorrida por toda parte pelos instantes do mito, do daimon de Sócrates passando pela metempsicose (Phaidon), do relato do Er (República) até a fabulação no Timaeus tratando do Um afetado pelo Outro, do ser do não-ser, da mescla da afirmação e da negação. 
O gesto filosófico de Platão em respeito à poesia é o distanciamento, diminuindo assim seu encanto ameaçante através de seu isolamento. $\mathrm{O}$ desterro dos poetas fora da cidade ideal é acompanhado pela elaboração rigorosa de uma terminologia tentando atingir a univocidade do sentido em detrimento das ambivalências da linguagem comum. A falha desse programa em nenhum outro lugar se torna tão óbvia como no mito da caverna da Politeia que, intensificado pelo brilho de toda a produção filosófico-literária de Platão, transforma o encontro desejado e proibido da filosofia e da literatura em desastre esplêndido.

O mito artificial da saída da caverna teve êxito incomparável. Por que as épocas ulteriores se reconheceram nele tão facilmente, independentemente das denominações variáveis do interior e do exterior, dos enganados e dos libertados? No paradoxo do reconhecimento pela primeira vez se manifesta uma evidência superior ao alcance da verdade proposicional que nos transforma em contemporâneos de Platão, mesmo sem ainda ponderar suas partes conceituais e figurativas. Considerada como fábula, a parábola da caverna, construída em torno do retorno do libertado para a caverna após ter visto a luz da ideia, segue a lógica da repetição com diferença, diferença decisiva de fato. Já no diálogo Protágoras, redigido antes da morte de Sócrates, os seres humanos são criados com fogo e chão pelos deuses no interior da terra antes de saírem para a luz. Todavia, não havia ali a menor hesitação em sair ou alguma recusa ao rumo traçado. A rejeição da oferta de abandonar a obscuridade subterrânea, exposta no sexto livro da República, deve ter suas próprias razões. Ao mesmo tempo, essa parábola contém indiretamente, disfarçado por trás do espetáculo teatral dos dramatis personae à sombra, um pequeno tratado lógico-ontológico sobre o ser e o não-ser, cuja premissa se encontra no diálogo Sophistes. O problema ontológico (como pensar o não-ser?) relaciona-se com o problema fenomenológico (como o não-ser aparece?). Em oposição a Parmênides (BADIOU, 2009, pp. 104-107), que nega a possibilidade do não-ser, Platão afirma o aparecimento da negação, do não-ser, pois, com efeito, sem dúvida as sombras no interior da caverna não são nada. Platão determina o não-ser já não como inexistente, mas sim como o diferente, ou outro, a não-identidade, a comunidade da imobilidade e do movimento. Participação paradoxal, também o nãoser participa do ser. Não se trata da existência do nada (oủ ov), e sim da ausência do ser determinável $(\mu \eta$ ov) que caracteriza duas formas distintas da negação. Não há diferença absoluta entre o ser e o não-ser, 
a relação da realidade endógena com a exógena do não, é nada. $\mathrm{O}$ nãoser não pode ser totalmente nada, a fala sobre o não-ser não pode ser simplesmente falsidade. Não fosse assim, seria impossível distinguir a ilusão das sombras da realidade das ideias. Apenas o nada parcial, apenas a fraude parcial é determinável; o nada total, a fraude absoluta, não. A teoria e a estética apresentam duas tentativas simétricas de apoderar-se da realidade mediante a desrealização dos seus objetos. Por conseguinte, apenas uma fábula teórica consegue narrar o modo como aquilo que resta indeterminável para a verdade do pensamento se torna acessível pela experiência pré-lógica e antipredicativa dos presos.

O dualismo platônico, inclusive suas aporias, requer ser compreendido como mediação ou participação que resulta do seu conceito da realidade. Longe de serem opostos, o mundo ideal e o mundo sensível têm de ser vistos em termos comparativos. Isso está salientado já no plano figurativo do texto: o fogo, o brilho das chamas, os olhos deslumbrados, as sombras, a luminosidade do dia, a luz do sol, a iluminação pelo dia subterrâneo e pelo dia metafísico constituem um só movimento impelido pelo mesmo comparativo que enfrenta, no degrau superior, um imperativo supremo. Não há negação absoluta; em todas as etapas desse caminho aparece a verdade - a visibilidade das sombras, a visibilidade das coisas como causas das sombras, a visibilidade da luz fora da caverna até a diafania da ideia -, mesmo que a forma do visível e o modo da visibilidade mudem sem trégua nessa cinética propedêutica, cujo ritmo prefigura a dialética hegeliana. Mesmo as duas situações extremas dessa ascensão, a ignorância inicial dos moradores da caverna e o acesso à esfera da luz verdadeira, são relacionadas com o alpha privativum: a-paideusia $\left(\dot{\alpha} \pi \alpha \_\delta \varepsilon v \sigma \iota \alpha\right)$ e $a$-letheia $(\dot{\alpha} \lambda \hat{\eta} \theta \varepsilon ı \alpha)$ destacam por duas vezes a necessidade da negação para o pensamento e o ser.

As sombras projetadas mediante a claridade do fogo na parede da caverna, por serem percebidas pelos cativos, evidenciam o poder básico da imagem aquém da sua função mágica: tornar o ausente presente. A presentificação de uma ausência, a substituição do real pela (ir)realidade figurativa gera a relação pré-linguística da imagem com o conceito, que não faz outra coisa se não tornar o ausente presente. Nisso se verifica a semelhança da arte com a filosofia no que diz respeito à apropriação da realidade, independentemente da imagem artificial (um cavalo pintado na parede) ou da imagem ilusionista (a sombra do cavalo projetada na parede). Platão parece não ver que a imagem não apenas é o oposto da sombra, 
mas também o precursor da ideia enquanto concentração da atenção em um ponto sensível. Nesse sentido, a postura irônica de Sócrates no que se refere à visão dos encadeados - "pessoas nessas condições não pensavam que a realidade fosse senão a sombra dos objetos" (PLATÃO, 1996, 515c) não leva em consideração a própria condição da parábola proferida por ele mesmo no início. "Imagina a nossa natureza, relativamente à educação ou à sua falta, de acordo com a seguinte experiência” (514a). O destinatário dessa iniciação, Glauco, tem de dividir a própria faculdade imaginativa com os presos para entender o sentido literal e figurado da parábola antes do seu progresso cognitivo. A essa altura, o balanço intercalado da teoria do conhecimento deixa ainda em aberto se toda desgraça decorre do pertencimento ou da comparação.

Mesmo o afeto mais filosófico, o espanto, parece duplamente insuficiente: como explicar o surgimento da parábola platônica no centro da sua teoria do Estado, como inserir essa parábola na tipologia da caverna mitológica caracterizada pelo nascimento do herói dentro da caverna, do Dioniso até Cristo, cujo estábulo oferece a versão mais civilizada da caverna (BLUMENBERG, 1989, pp. 43-44). É necessário arrancar o mito artificial da caverna platônica do convencionalismo da recepção a fim de tornar mais suscetível sua irritante atração. A abordagem desse assunto é tríplice. Por que os seres humanos estão desde sempre na caverna? Quais as condições da vida e da sobrevivência dentro da caverna? Como sair da caverna? A posteridade do platonismo envia a pré-história esquecida por Platão a fim de dar conta da entrada imemorial da humanidade num recipiente quase-encerrado que assegura sempre menos o equilíbrio entre o abrigo e o cativeiro. No entanto, as categorias filosóficas são ligadas às experiências históricas; mesmo a metafísica é saturada de política. Os elementos comunistas da crítica de Platão à Polis decadente marcam as forças centrífugas para escapar à corrupção democrática. Na época do declínio do império romano, essa corrupção atinge o seu valor limite na filosofia gnóstica, considerando o mundo inteiro como prisão erguida pelo mau demiurgo. ${ }^{1} \mathrm{O}$ inferno dantesco retoma a obsessão da inclusão fatal na ótica da jurisdição divina. Ainda as luzes pertencem a essa linhagem herética do êxodo quando Kant (1986, p. 7) afirma: "Esclarecimento

1 O neognóstico Adorno: "No mundo transformado em prisão de ar livre, não importa o que depende do que, tudo é a mesma coisa" [In dem Freiluftgefängnis, zu dem die Welt wird, kommt es schon gar nicht mehr darauf an, was wovon abhängt, so sehr ist alles eins] (ADORNO, 1976, p. 25). Todas as traduções do alemão são nossas. 
[Aufklärung] é a saída do homem de sua menoridade, da qual ele próprio é culpado". ${ }^{2}$

Há uma dialética particular do esclarecimento. A imagem arquetípica da caverna platônica e da sua perda forçada ou inevitável recorda também a violência das separações filogenéticas e ontogenéticas (o nascimento, a infância, Ítaca, a transição da vida intramarina para a terra) para alcançar a autonomia do Eu, já não envolvido no mundo mas sim exposto a ele. O Século das Luzes vangloriava-se mais que qualquer outra época dessa autonomia humana e, conforme a compreensão que tinha sobre o assunto, a caverna é um símbolo ultrapassado para manifestar a presença do homem na terra que se torna a sua casa. A equação mundo=casa substitui aquela do mundo=caverna. A civilização burguesa se refere ao mundo na qualidade de casa própria, cuja economia doméstica é atendida por cidadãos urbanizados, domesticados. Nessa interioridade global, prossegue o $\alpha \gamma \omega \dot{v}$, a competição dos presos platônicos na caverna. Enquanto eles rivalizam em predizer e recordar com mais precisão a sucessão das sombras para ser mais poderosos e honrados, os donos da casa mundial convocam a um novo concurso, ou seja, a uma concorrência democrática no capitalismo parlamentar - "Quem é o melhor democrata?" - num momento histórico, quando os alicerces da sociedade - o capitalismo, as finanças, a economia, o exército - ficam excetuados de qualquer democracia, mesmo no sentido aritmético da mera contagem.

O mesmo século XIX atesta a diferenciação interna do logos, acompanhado por seu alargamento exterior. A razão pós-idealista abrange as dimensões da economia, da linguagem, do imaginário e do inconsciente, cujos respectivos discursos reivindicam um monopólio explicativo. O próprio conceito de "discurso" indica uma alteração da modalidade epistemológica que dessubstancializa a unidade da razão e da história em prol de configurações contingentes desprovidas das sínteses necessárias. A erosão da ordem ontológica, assim como a da ordem clássica do saber, resulta em uma erosão do sujeito, pouco depois que precisamente esse sujeito assumiu a abandonada posição de Deus. A abdicação do Eu em favor das forças anônimas e descontroladas se resume em várias autodenúncias consecutivas.

Já em 1806, Fichte, criador do Eu absoluto, descreve a dependência do homem a uma força imaginativa ameaçadora, que o arrasta rumo ao desconhecido. "Por toda parte eu não sei de nenhum ser, tão pouco do

2 "Aufklärung ist der Ausgang des Menschen aus seinerselbstverschuldeten Unmündigkeit." Remate de Males, Campinas-SP, v. 37, n. 1, pp. 449-470, jan./jun. 2017 
meu próprio ser. Há nenhum ser. Eu mesmo não sei de modo algum, e eu não sou. Há imagens, elas são o único que é [...] Eu mesmo sou uma dessas imagens" (ADORNO FICHTE, 1965, p. 245).3 Apenas poucas décadas depois se encontra a variação do mesmo tema na crítica da economia política. A precedência objetiva das estruturas capitalistas baseadas em categorias do trabalho assalariado, do lucro e da acumulação predetermina a consciência e as ações dos indivíduos como um destino cego. A autovalorização do valor [Selbstverwertung des Wertes] atua como sujeito dinâmico que degrada os capitalistas em personificações das leis do mercado e os trabalhadores em anexo da produção. Segundo Marx (1968, p. 57): "Eles fazem-no sem o saber. Portanto, o valor não tem, escrito na fronte, o que ele é. Longe disso, ele transforma cada produto do trabalho num hieróglifo social". ${ }^{4}$

A terceira condição da impossibilidade, o terceiro transcendental histórico, é a linguagem. Enquanto o idealismo a determinava, seja como a mediação do finito e do infinito, seja como ser do espírito ou da unidade do particular e do geral, uma outra linhagem esclarece os mecanismos dessublimados da coerção linguística. O aforismo de Lichtenberg inicia o linguistic turn da filosofia moderna. "A nossa filosofia errada é encarnada na linguagem inteira. Por assim dizer, não podemos raciocinar sem raciocinar falsamente [...] Seria preciso dizer id pensa assim como se diz relampeja" (LICHTENBERG, 1975, p. 412, grifo do autor). ${ }^{5}$ A gramática como prisão, a junção sujeito-objeto como cela e a proposição predicativa como grades, nessa claustrofobia, nesse interior sem exterior, se instalam também os depoimentos de Nietzsche (1980, p. 78) - “Temo que não nos livramos de Deus enquanto acreditamos ainda na gramática” - ${ }^{6} \mathrm{e}$ Wittgenstein (2009, pp. 5-6) - "Os limites da minha linguagem significam os limites do meu mundo".

\footnotetext{
3 "Ich weiss überall von keinem Seyn, und auch nicht von meinem eigenen. Es ist kein Seyn. Ich selbst weiss überhaupt nicht, und bin nicht. Bilder sind: sie sind das einzige, was da ist [...] Ich selbst bin eins dieser Bilder."

4 "Sie wissen das nicht, aber sie tun es. Es steht daher dem Werte nicht auf der Stirn geschrieben, was er ist. Der Wert verwandelt vielmehr jedes Arbeitsprodukt in eine gesellschaftliche Hieroglyphe."

5 "Unsere falsche Philosophie ist der ganzen Sprache einverleibt; wir können sozusagen nicht raisonnieren, ohne falsch zu räsonnieren [...] Es denkt, sollte man sagen, wie man sagt, es blitzt."

6 "Ich fürchte, wir werden Gott nicht los, weil wir noch an die Grammatik glauben".

7 "Die Grenzen meiner Sprache bedeuten die Grenzen meiner Welt."
}

Remate de Males, Campinas-SP, v. 37, n. 1, pp. 449-470, jan./jun. 2017 
A quarta revogação da razão provém dos impulsos (instintos?) sexuais que desmentem a soberania da consciência. Sob o título do inconsciente, Freud (1972, p. 251) nota a invasão de uma força dentro do Eu, irredutível à forma do Eu: "que somos habitados por forças desconhecidas e descontroladas". ${ }^{8}$ Os nomes criam as coisas, mas a hegemonia secular da psicanálise não deve fazer cair no esquecimento o fato de que a nomenclatura filosófico-teológica lida desde sempre com essa dimensão menor e maior do que o sujeito. A história ainda não escrita da relação do Eros e da razão começaria com Platão. Nele, a aspiração à verdade é prefigurada no impulso erótico que, assim que devidamente orientado, materializa a faculdade suprema do sujeito de se autotranscender já no nível somático. O Eros platônico é um professor auxiliar para a divulgação da doutrina da ideia. Em seguida, essa harmonização logocêntrica do corpo e do espírito será duplamente quebrada. Por um lado, pela "espinha na carne" (Coríntios II, 12, 7) de São Paulo, por outro, pela teoria das percepções pequenas de Leibniz, pequenas demais para ultrapassarem o limiar da percepção consciente, mas continuamente eficientes. Schelling marca a etapa seguinte na pré-história do inconsciente quando põe o "Ungrund", o sem-fundo, dentro de Deus: o impensável donde derivam todos os seres mortais.

No decorrer do tempo, da antiguidade até a modernidade, o Eros se afasta sempre mais da razão para constituir, afinal, uma heterogeneidade hostil ao pensamento que Schopenhauer identifica com a vontade cega do instinto da vida, da autopreservação. Assim, o intelecto aparece como epifenômeno, força derivativa e secundária que obedece a uma força mais elementar. Resultado paradoxal: os mesmos procedimentos que prometerama extensãodaluzda razão, por meiodoesclarecimentodosseus fundos, são discursos sobre a natureza imaginativa, ideológica, linguística e libidinosa do homem que conduzem a obscurecer, diminuir, dissolver e destituir a razão. A autorreflexão da consciência acaba por admitir uma quantia sempre maior de irracionalidade. No final das contas, a própria razão passa ao segundo plano. Reformulando na terminologia platônica: as saídas da caverna se transformam em novas prisões, novas cavernas que apenas se confinam a outras cavernas com sombras ainda mais longas. Os quatro autoencerramentos da razão moderna multiplicam a caverna platônica e igualmente a invertem. O corpo deixa de ser a prisão da anima e agora a própria consciência é detida por si mesma.

8 “daß wir [...] gelebt werden von unbekannten, unbeherrschten Mächten." 
Apesar da preponderância da visibilidade, os presos da caverna platônica não são mudos. Conversam, dão opinião sobre as sombras que passam e lhes dão nomes, entram em discussão com os companheiros. A decisão ontológica de Platão de admitir a existência do não-nada revela aqui suas implicações linguísticas. As figuras de linguagem utilizadas pelos presos não podem ser inteiramente falsas sem ser, por essa razão, necessariamente verdadeiras. E os sofistas se aproveitaram dessa situação. Se a verdade se torna inacessível para o conceito, só sobram as técnicas da enunciação e as posições subjetivas do locutor. Abre-se o campo dos discursos plurais, da multiplicidade dos jogos linguísticos [Sprachspiele] e da heterogeneidade dos nomes. A esse respeito, a filosofia pós-moderna, movida pela desconstrução, pelo différend, pelo fragmentarismo, pelo respeito à alteridade e por um je ne sais quoi, renova as apostas do primeiro sofismo num antiplatonismo generalizado, assegurado por seu conservadorismo político. Se o ser se torna intercambiável com o ser dito, os discursos desvinculados de toda adequação ontológica em favor da própria demiurgia se entregam ao reino da ficção (CASSIN, 1995, p. 127). A flexibilidade e a variância da língua causam a cumplicidade da sofística e da poesia. Fazer coisas com as palavras equivale a possuir o mundo, e nisso consiste o vínculo da retórica com a política, alheio ao Bem uma vez que o ser já não é revelado pela palavra, mas sim criado pelo discurso. A retórica substitui a ontologia. Quem quer que se torne mestre do discurso disporá do ser e do não-ser e decretará as leis da admissão de visibilidade: a Polis de Atenas só conhece cidadãos, não escravos; as democracias ocidentais só toleram democratas, nunca pobres. Contra a política de gestão administrando os pseudos das narrações oficiais, contra a submissão da política à necessidade, contra o imperialismo linguístico, Sócrates, no debate da legitimação do nome no Crátilo, insiste que os filósofos partem das coisas como são em si mesmas, ao invés das palavras.

A contemporaneidade é inquietação. Se quisermos que não apenas Platão seja nosso contemporâneo, mas também que nós próprios sejamos os seus, há que retomar sua doutrina da verdade na condição do presente. Isso obriga a repensar o conceito de objeto, a negação e a ideia. A intervenção de Sócrates mencionada acima se refere a uma polêmica que contesta a hipótese sofista de que as coisas são apenas distinguíveis dentro do discurso. Seja qual for a explicação dessa questão, nela aparece o problema do início da filosofia, que ressurge de modo diferente ao longo do século XX. Se Sócrates escolhia a coisa como ponto de partida, 
na vivência atual parte-se, ao contrário, do desaparecimento das coisas. Sumiço quádruplo: as coisas na qualidade de mercadorias não são feitas parar demorar nem os lugares para parar, o presente desvinculado do passado e do futuro se torna mero presentismo sem profundeza temporal, a ordem das coisas é substituída pela ordem das imagens, na medida em que o mundo das coisas se transforma em mundo dos desejos e a ontologia se transforma em "hontologie" (LACAN, 1991, p. 127).

Isso afeta a compreensão da realidade dentro da caverna pósmoderna, assim como a fronteira entre o dentro e o fora. Através do único cativo desatado e obrigado a olhar firmemente para a luz, será introduzido um comparativo ontológico que precede o superlativo. Só a partir dessa saída para fora se explica a artificialidade da situação inata dos presos, só agora a irrealidade daquilo que eles consideram como realidade se mostra evidente. Ainda que os presos enfrentem as sombras projetadas das coisas, ainda que denominem as sombras, não sabem o que é uma imagem. A sequência ininterrupta das imagens impossibilita esse conhecimento. Ficam sem conceito porque não conseguem relacionar o presente com o ausente. A exclusividade da caverna lhes impede. A impossibilidade de que a realidade seja diferente explica o consentimento ao espetáculo subterrâneo. Unicamente a partir da diferença dentro-fora a realidade pode ser concebida como possibilidade. Assim que essa modalidade, tanto perceptiva quanto lógica, falta, falta também a capacidade da negação. $\mathrm{O}$ que existe poderia igualmente não existir, o que não existe poderia igualmente existir - e essa alternativa é impossibilitada no interior subterrâneo. Ali, a realidade não se transforma apenas em melhor prova da possibilidade, mas sim em sua única prova.

A realidade endógena e tudo o que lhe é inerente obedece ao princípio do previsível. Apenas é real aquilo que pode ser previsto, que resta provável, sustentado pela certeza de uma temporalidade passiva e indolente, de que a qualquer momento chegará a sua vez. Repetida numa sequência mais empírica: o próximo salário, a próxima guerra, o próximo filme, a próxima demissão. Contudo, o aumento da probabilidade não se aproxima da verdade; o único progresso é aquele da habituação gradual a esse mundo estático. Nele, a negação perde a sua função porque nenhuma correção parcial poderia melhorar a realidade, salvo a modificação integral dela em nome da ideia. O que acontece assim que a fórmula do realismo socrático - nós, os filósofos, presumimos as coisas como ponto de partida - deixa de vigorar por causa da carência das coisas? Chega a 
hora dos sofistas que criam imagens mais sugestivas. Os antigos sofistas as produziram retoricamente - a persuasão, para além de estar à venda, era linguística, pois toda a realidade é inscrita no discurso. Dessa maneira se verifica o derradeiro sentido do logos significando também fatura. Platão desprezou os sofistas por terem renunciado ao absoluto em favor das eidola da persuasão retórica, encantando os ouvintes. Nisso os sofistas precederam os sacerdotes fraudulentos e hipócritas. Contudo, o princípio para se conseguir produzir um impacto real permanece inalterado: a actio in distans, exige, pois, um afastamento espacial mínimo para alcançar os resultados desejados; técnica refinada pelos mais hábeis no raciocinar e no uso da voz e do gesto para obter ascendência sobre o auditório.

Com a perda dessa distância emergem os novos sofistas, dandose a conhecer a nova caverna e seus respectivos simulacros e criadores de aparência. Na assembleia ateniense, aqueles que possuíam dons de oratória pediam a palavra. As assembleias tiveram lugar apenas esporadicamente, quando havia algo a chamar a atenção pública. No novo regime, na segunda era do sofismo, essa assembleia, assim que a produção técnica das imagens penetra todas as parcelas da realidade, se reúne continuamente, assembleia que abrange todos aqueles que são presos do novo tipo do olhar, novo tipo de imagens artificiais emitidas pela autoridade das telas. Ao contrário das imagens verbais, voltadas para o imaginário dos ouvintes, as novas imagens já não podem ser imaginadas ou interiorizadas, pois não pertencem à espécie "imagem visual". São imagens táteis que afetam o olhar como um objeto físico extremamente acelerado. Nesse abandono da distância entre o sujeito da percepção e a imagem percebida se realiza aquilo que na retórica do primeiro sofismo ainda era metáfora: o efeito imediato da imagem-choque e da acústicachoque sobre a mente humana, sem os desvios da mediação verbal. Sob os efeitos intensificadores e amortecedores das imagens táteis onipresentes, a primeira realidade das coisas e a segunda realidade das imagens se interpenetram até a indistinção delas. ${ }^{9}$ Instáveis e flutuantes, contínuas e instantâneas, as imagens táteis comunicam sua particularidadeà realidade

9 A afirmação de Freud de que o inconsciente encontra na palavra e pela palavra sua articulação essencial, exige ser reformulada a favor do imagético. Sobre o caráter onírico da realidade, ver Christoph Türcke (2012, pp. 72-73). Acerca do novo tipo de desapropriação, ver Gilles Deleuze (2007, pp. 207): “O fato moderno é que já não acreditamos neste mundo. Nem mesmo os fatos que nos acontecem, o amor, a morte, como nos dissessem respeito apenas pela metade. Não somos nós que fazemos cinema, é o mundo que nos aparece como um filme ruim".

Remate de Males, Campinas-SP, v. 37, n. 1, pp. 449-470, jan./jun. 2017 
que será percebida de modo sempre menos estável, contínuo e duradouro. A própria fronteira entre a psique e o físico, a presença e a representação, se torna instável e flutuante.

Na medida em que a imagem substitui a linguagem como condição de acesso ao mundo e ao Eu, o estatuto da negação muda. Por causa do seu mero ser, a imagem constitui uma força pré-predicativa da afirmação. Uma frase afirmativa pode ser negada, não uma imagem, já que sua forma não é predicativa. Mais profunda, mais arcaica do que a afirmação ou a negação linguisticamente explícita, a imagem torna toda autojustificação supérflua ao levar consigo o seu próprio ônus da prova, indiferente a "não" e "sim". Como tautologia pré-lógica, sua força imobilizadora visa impossibilitar a crítica. Daí a dificuldade de dizer não em face da realidade reduzida à visibilidade.

Sob as condições da irradiação do cinematógrafo mundial, cujos organizadores cuidam da variação do espetáculo a fim de manter a crença endógena nas ilusões tomadas pelo ser, se perfila um novo heraclitismo,

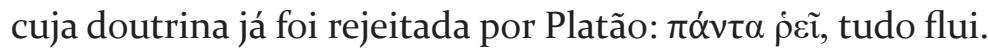

Como sair vivo da caverna, como escapar ao cinema global, como deixar o campo de desconcentração imenso, como acabar com as narrativas curtas da identidade? A procura da saída complica-se ainda mais, pois o mundo encerrado no capitalismo já não admite algo de incomensurável ou exterior a sua esfera, só a distribuição das posições dentro dessa interioridade mundial ligada à estima recíproca das sombras tolerantes. Só essa antropologia invertida explica retroativamente a artificialidade inata da posição dos prisioneiros platônicos nem minimamente espantados de estarem atados. Tudo é relativo a esse destino cuja epistemologia condizente é o relativismo que relaciona diferenças com diferenças para se fazer mais diferenças, e assim por diante. Por esse realismo cru, qualquer aspiração à "ideia” seria apenas uma ilusão mais refinada.

O que leva o homem a se autocompreender já não no espelho das imagens exteriores, dado que a força imaginativa dentro da caverna não pode tornar-se erupção? De que forma o real pode ser pensado relativo à ideia? No início da sua Metafísica, Aristóteles faz prova da sua fé no sentido comum ao decretar que todos os seres humanos possuem o desejo de saber. Desse modo se inicia uma longa sequência filosófica, ao pressupor a conaturalidade do homem e do saber. Por Platão, a situação inicial se caracteriza precisamente pelo contrário. Ninguém parece de modo algum disposto a meditar, ninguém tem a mínima vontade de 
fazer filosofia, basta passar a vida a fazer negócios e mais nada, in cunctis domina pecunia est [em todas as questões domina o dinheiro]. Já os presos da caverna teriam motivo para temer as suas próprias reflexões. Donde se segue que nada haverá a esperar do livre-arbítrio. Que tipo de negação consegue superar o dilema do autocentrismo rumo à ideia? Ela necessita vir do lado de fora. Platão inaugura esta outra linhagem do pensamento, originada no involuntário e na violência, ligando Atenas ao caminho para Damasco tal como para Combray. Para explicara resistência ao pensamento empiricamente inexplicável, Platão, de certa maneira, a temporaliza. Através da doutrina da preexistência da alma se cria uma nova modalidade do tempo para descrever a opacidade própria do pensamento, não mais um simples desconhecimento, mas sim a má vontade inerente a ele, que não tem boa índole (DELEUZE, 2009, p. 206). A teoria da preexistência da alma em relação ao corpo se iguala a um passado que nunca foi presente. A alma humana, antes do nascimento, antes do cárcere do corpo, teria contemplado as ideias enquanto seguia o cortejo dos deuses. Encarnada, perde a possibilidade de contato imediato com as ideias. Apenas a tenacidade do esquecimento é testemunha do conhecimento imemorial das ideias incorpóreas, o qual antecedia o conhecimento fornecido pelos sentidos. Conhecer seria então lembrar, reconhecer. Mas a parábola da caverna se destaca justamente pela ausência da doutrina da preexistência e daquela correlativa da reminiscência. Isso é o primeiro indício de que, no meio da Politeia, conhecer poderia ser diferente de lembrar, algo além de reconhecer a necessidade, cujo arquétipo é o Estado.

Platão corta o liame entre verdade e busca em favor das aventuras do involuntário. Algo tem de advir do outro lado. Enquanto a subjetividade não vale nada em si para alcançar a verdade, restam as forças do exterior que advêm por parte da violência. No mito da caverna, nada acontece de maneira voluntária. Os presos não podem voltar o rosto, forçados a manter imóveis suas cabeças durante toda a vida. Sem qualquer intervenção própria, um deles é desatado e obrigado a levantar-se, a volver a cabeça, a fitar o fogo, a andar fora e olhar para a luz do sol, entretanto é ofuscado pelo brilho do Bem. Finalmente, no retornado à caverna, é ameaçado de morte. Tudo acontece como se a ausência de dor fosse igual à presença do mundo imaginário dentro da caverna, enquanto a presença da dor fora dela equivale à irrupção da ideia revoltada à habituação.

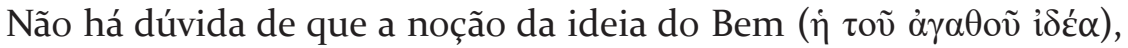
aperfeiçoada ao longo da obra platônica, é hiperdeterminada: superlativo 
lógico-ontológico, fundamento da verdade, ponto fixo e irreflexivo da reflexão, princípio supremo sem ser a ideia das ideias, princípio de conhecimento e de cognoscibilidade, princípio da realidade, além do Um pitagórico ealém do Um inteligível, lugares anônimos para além da essência

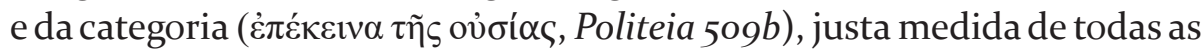
coisas, absoluto irrelacionável e por isso indefinível, irrepresentável como os irracionais matemáticos, limitação da linguagem, vai além do discurso, força que submete a palavra à lei da verdade, momento da transição da dialética em metafísica, aquilo que expõe o ser à ideia. De certa forma, todas essas determinações são empenhadas no momento do encontro do libertado com a ideia do Bem. Na zona de indistinção da imanência e da transcendência, do ser e do ter, o homem discerne (vislumbra) algo do ser que não pode ser absorvido pela frase, algo do acontecimento que não pode ser absorvido pela realidade,$^{10}$ algo do pensamento que não é condicionado pelo sujeito, algo do tempo irredutível à cronologia de imagens regulares. O enfraquecimento dos objetos no nível empírico se converte em forma suprema do Eros, amor sem objeto, mas, desta vez, enriquecido da verdade do amor: inimigo do mundo tal e qual. Platão contorna aqui uma experiência não mais ótica, mas sim que está em contato direto com o Bem que perpassa o ser humano até que ele mesmo se torne parte do Bem. Superior às propriedades particulares e idiossincrasias subjetivas do Eu, a ideia do Bem, ao oferecer aquilo que não tem, cria um dom que transforma a palavra "Eu" em mentira. O que seria o infinitivo do Eu?

Emancipado da trivialidade quotidiana, dispensado das aclamações de herói do dia, privilegiado pelo absoluto, favorito da ideia, por que o libertado não fica por aqui, satisfeito da sua conversa particular com o sobre-humano? Por que não encontra a paz? Por que desfruta da sua liberdade só como libertação antecipada ou condicional?" Porque a abertura instantânea do outro mundo significa desejar este mundo aqui como outro, pelo menos por um instante. O alpha privatum da $\dot{\alpha} \lambda \hat{\eta} \theta \varepsilon \iota \alpha$ grega constitui um vínculo entre a verdade e o retorno da alma (Пврı $\alpha$ үоү

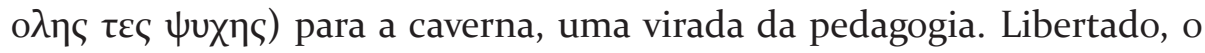
homem se torna livre para que o efeito da verdade possa ser divulgado,

\footnotetext{
10 Ver a metafísica mínima em Adorno (1975, pp. 164 e 367): "Was ist, ist mehr, als es ist" [O que é, é mais do que é]; "Das Innere der Gegenstände als diesen zugleich Entrücktes" [O interior das coisas como simultaneamente trasladado delas].

11 A exceção, inclusive o seu sinônimo jurídico de privilégio, é precursora do genérico. Quando o Cristo saiu da outra caverna, a tumba, só iniciou a ressurreição de todos ao acreditar na apocatastasis.
}

Remate de Males, Campinas-SP, v. 37, n. 1, pp. 449-470, jan./jun. 2017 
maximizado dentro da caverna. Não há verdade particular. A ideia cuja fascinação é genérica não admite tratamento preferencial nem sequer maiorias democráticas, pois a libertação verdadeira de um só coincide com a abolição do cativeiro dos demais. Há vários nomes para essa conversão instigada pela convergência do Eu ultrapassado e do excesso da ideia do Bem, mas sempre a verdade é ou universal ou nada, ou coletivo ou fraude. Três exemplos. 1) A física saiu da caverna para descobrir os elementos básicos da matéria. Voltando para a caverna, será construída a bomba atômica. Aí o problema não é a física atômica, mas sim seu uso particular e mortal; 2) Marx analisa as estruturas mais íntimas da economia capitalista desvendando os mistérios da mais-valia. Os sucessores dele, afiliados do socialismo estatal, voltam para a caverna a fim de erguer as tábuas das leis históricas do materialismo dialético; 3) Na crise financeira de Europa, o cineasta Jean-Luc Godard fez uma proposta simples para resolver o problema das dívidas gregas. Os gregos tinham criado as noções básicas da nossa lógica. Sempre que um europeu utiliza a lógica grega na sua fala, deveria transferir dez euros para a Grécia. Caso contrário, perderia o direito de utilizar esta lógica.

Não obstante, não é a luz da ideia que sofre desses obscurecimentos temporários, não há agonia do bom fundamento, é só uma questão da boa oportunidade. Enquanto persiste o culto do sucesso e a adoração do egoísmo, a parte mais escura, mais real do homem não oculta os vícios que encobre, mas sim as virtudes que ele ainda não conseguiu demonstrar.

De modo semelhante à situação singular do único libertado da caverna, nem mesmo Deus conseguiu ficar sozinho com a sua verdade. Sozinho lhe foi impossível cumprir sua tarefa. Isso remete de novo para a questão da negação, à qual se junta uma dimensão vertical. Platão criticou os sofistas por oporem um "não" a qualquer tese. A contestação acabou simplesmente em autoconfirmação sem aumentar o conhecimento. O primeiro tipo da negação trata da negação do não-ser; contesta uma frase afirmativa ao negar a existência positiva do seu conteúdo. $\mathrm{O}$ outro tipo da negação ressalta a segunda dimensão da negatividade: aquilo que não deveria-ser e igualmente aquilo - no sentido da falta ou da ausência - que deve ser abordado como errado (THEUNISSEN, 1983, pp. 41-42). Essas duas formas de negação, aquela ontológica e esta moral, o Bem que deve ser e o mal que não deve ser, se reúnem na ideia do Bem platônico. Dessa maneira, a superioridade ontológica do Bem se torna imperativo moral. Escapado da caverna, o libertado só poderia contentar-se com a 
contemplação do Bem se este for uma entidade metafísica cujo modo de ser seria apenas o comparativo da contemplação dos objetos físicos: presença superior, mas mesmo assim presença. Porém, a ideia do Bem atua como irradiação, como força inseparável de seus efeitos. Atua como remetente que convida, ou seja, obriga seus destinatários a torná-la uma realidade ao fazer o máximo uso dela. Nesse impulso se finaliza a tarefa subversiva da participação e imitação quando o mensageiro se torna indistinguível da sua mensagem. O Bem se inicia com o autoesquecimento do Eu. Há um núcleo de virtude em todo ato de conhecimento. O Bem e o Ser convergem assim como a liberdade e a necessidade, o livre-arbítrio e a obediência. Não se sabe se a moral permite o plural, mas não é por acaso que os maiores testemunhos dela culminam num imperativo, dos dez mandamentos até o imperativo categórico de Kant. Em Platão, a ideia do Bem contém um lado pessoal que comove seus sujeitos, sendo ela, nisto, semelhante a Deus - trahe me post te. A fórmula da liturgia católica sursum corda - habemus ad dominum aponta de novo para a unidade paradoxal do movimento e da beatitude, dialética da eternidade não desconhecida de Platão. "Não é fácil ser eterno" (PLATÃO, 1996, 611b). Só esta origem meio pessoal do supremo impede que o homem, uma vez desatado do mundo subterrâneo, não caia na indiferença abismal de fazer o Bem ou o mal. ${ }^{12}$

A ascensão para a ideia se coloca no centro da teoria platônica da política. Assim, o Bem enfrenta dois perigos, cujos equivalentes subjetivos são a paciência ruim e a impaciência ruim. Ou ser infinitamente adiado e desrealizado no horizonte da ideia regulativa para virar referência de especulação perene de certo, ou ser assimilado a um regime político concreto combinado com o aparelho do discurso científico. A posição geográfica de Atenas, situada a meio caminho entre Jerusalém e Siracusa, materializa essas tensões. Os nomes dessas cidades simbolizam as três tendências da filosofia: 1) Jerusalém: o êxtase do lugar, a sacralização do nome (Ernst Bloch: Ubi Lenin, ibi Jerusalem), o pensamento como iniciação reservada a poucos, a adulação do líder meio-transcendente (o ser-como); 2) Atenas: a fundação da academia retirada do comércio da vida, disputas verbais, os professores da faculdade (o ser com); 3) Siracusa: a intervenção nos assuntos mundanos, a organização da cidade

12 "Me interroguei tantas vezes, e não consegui encontrar uma resposta, sobre de onde vem o brando e o bem, não sei tão pouco hoje e tenho que ir agora" [Ich habe mich oft gefragt und keine Antwort gefunden, woher das Sanfte und das Gute kommt, weiss es auch heute nicht und muss nun gehen] (BENN, 1953, p. 21).

Remate de Males, Campinas-SP, v. 37, n. 1, pp. 449-470, jan./jun. 2017 
ideal, o reino do comunismo como nome político da ideia do Bem (o ser igual). Solicitado pelo jovem Dion, cunhado do tirano Dionísio I, Platão (2011, p. 63) ia então a Siracusa, na corte de Dionísio II, "imbuído de um intenso desejo de ingressar na vida pública”, concretizar o ideal da Politeia do Estado comunista governado por um rei-filósofo. De antemão se levanta uma objeção histórica. Siracusa, a cidade-Estado mais luxuriosa do mundo grego, não foi o local apropriado para tentar realizar o modelo político proposto na República. Na melhor das hipóteses, Siracusa poderia aproximar-se do modelo mais autoritário do Estado delineado nas Leis, tentativa de conciliação entre monarquia constitucional e democracia, o segundo melhor governo pelo império das leis. Levanta-se também uma objeção anedótica. Em 1933, quando fez o seu discurso inaugural como reitor da universidade de Freiburg, sob os nazistas, Heidegger glorificou o fascismo alemão por meio de uma citação da República (PLATÃO, 1996, 497d 9) a fim de estabelecer um paralelo entre o início grego e o destino do povo alemão. "Ta megala panta episphale" - "Pois tudo o que é grandioso está em meio à tempestade" -, tradução deliberadamente equivocada de sua excelência para "pois tudo o que é grandioso, é perigoso". O fracasso de Platão na Sicília, estando ele suscetível ao apelo do tirano da Magna Graecia, e a demissão vergonhosa de Heidegger, estando ele suscetível ao apelo do terceiro Reich - esses dois acontecimentos, de modo algum circunstanciais, seriam suficientes para desacreditar toda a incursão filosófica na política. ${ }^{13}$ Mas as coisas ainda se agravam. Dion banido de Siracusa, Platão afastado da corte por Dionísio II, nem minimamente disposto a orquestrar reformas políticas em Siracusa, mas, ao contrário, se tornando ainda mais tirânico, a aventura malograda do Estado comunista teria dado origem ao fascismo siciliano, cujo avatar moderno seria o regime nazista. No passo seguinte, o comunismo será identificado com o fascismo, os gêmeos do poder totalitário. Por conclusão, os filósofos fariam melhor em se abster e voltar para a academia preocupados em escrever ainda mais artigos, em organizar ainda mais conferências, progredindo na ascensão vertical dos servidores públicos. A filosofia redutível à rotina corresponde à política redutível à gestão de negócios. $\mathrm{O}$ fim da filosofia coincidiria com o fim da política, senão repensar o sintagma da filosofia política.

13 Após a demissão do cargo de reitor da universidade de Freiburg, o professor Heidegger foi saudado pelo seu estimado colega Wolfgang Schadewaldt: "Então, Senhor Heidegger, você está de volta de Siracusa?” [Nun, Herr Heidegger, Sie sind zurück aus Syrakus?] (WEIZSÄCKER, 1977, p. 246). 
O platonismo do século XXI se inicia com a redefinição da ideia no pensamento de Alain Badiou. Ele procede a partir da exigência ontológica, que deveria ser algo diferente dos corpos, das linguagens e imagens. Essa base negativa conduz a uma inversão da noção de participação. Enquanto Platão a fundou nos graus intermediários da mimesis entre os objetos sensíveis e as ideias, a ideia, para Badiou, obsta a absolutização do mundo empírico, impossibilita a eternidade do provisório. Assim, a própria ideia ou a verdade deve ser pensada como vazio. "A categoria vazia da verdade" e "a categoria central da filosofia explicitamente tem[têm] de permanecer vazia[s] [...] este vazio é a condição da ação real” (BADIOU, 2012, pp. 15 e 20, respectivamente), ${ }^{14}$ numa acepção plenamente metafísica. Nenhuma situação real esgota a ideia que não admite ser realizada inteiramente no tempo. A situação siracusana desmonta-se, inverte-se desde que o nome do filósofo-rei inaugura a sequência longa das identificações da ideia comunista com uma política particular, de Dionísio II até Stalin, marcada por prescrições tirânicas cuja forma presente é o mercado mundial. Visto que a história é marcada pela continuidade de todo tipo de poder, com as consequências que todos conhecem, é notável que ainda se encontre alguém interessado em tornar-se presidente, general, senador ou pelo menos chefe. Daí a pauta do dia: as eleições negativas, a competição para não chegar ao poder; tal como usualmente se faz de tudo para chegar ao poder.

A noção de identidade tem múltiplo significado. Designa a unidade da consciência individual, a igualdade consigo mesmo, o pertencimento ao genérico e a coincidência epistemológica do sujeito com o objeto. Quando a unidade do Eu, o seu direito de ser, é equiparada à sua concordância com a razão genérica do social, quando a razão genérica é equiparada a um corpo político existente (a corte de Siracusa, o partido comunista), a identidade atinge sua circunferência mais desastrosa, sendo equivalente a terrorismo. A ideia é considerada como já existente, já presente, inteiramente materializada numa estrutura política particular. Aquilo que foi irredutível a qualquer presença se torna o mais presente, o único ser, qualquer insuficiência ou imperfeição cabe aos indivíduos particulares que carecem de realidade face ao realissimum da ideia. Por conseguinte, o aniquilamento deles somente nega o que não existe, o que não deveria existir. A negação do não-ser apresenta a base lógica que

14 "The empty category of truth" e "philosophy's central category must explicitly be kept empty [...] this void is a condition for a real operation".

Remate de Males, Campinas-SP, v. 37, n. 1, pp. 449-470, jan./jun. 2017 
explica a facilidade dos massacres cometidos em nome do comunismo dogmático. Não é a existência do comunismo que é problemática, mais sim sua particularidade. Ademais, enquanto o número de mortos permanece o critério da verdade da política, nem a democracia nem o liberalismo tornam-se melhores.

A negatividade da ideia do comunismo em Badiou não implica a ignorância da história, mas sim se opõe ao niilismo pós-moderno, atuando em ausência de qualquer ideia numa temporalidade maior que os primeiros cinco milênios da história humana. Precisou-se de quinhentos anos para impor o capitalismo; será necessário talvez um tempo ainda maior para desfazer os efeitos mais fatais dele em favor da uma ordem social superior. Assim, a eternidade permanece o atributo da verdade, mas apenas na qualidade de categoria do porvir. A transcendência da ideia política não é unicamente privação, pois opera como força dos procedimentos de verdade. Um procedimento de verdade é o acontecimento que enche o vazio do tempo histórico regular, que interrompe o automatismo do lucro, que transgride o monopólio do Estado, que irrompe a ordem do discurso hegemônico. Um dos nomes dessa suspensão éa política movida pela ideia do comunismo. A ideia é a alteridade inerente ao sujeito, o devir-outro se entende sempre no sentido vertical. Nos momentos excepcionais da história ligados às revoluções $(1789,1848,1918)$, esta verdade entretanto se torna presente, quer dizer, torna-se acontecimento. Nele vem à realidade aquilo que foi inexistente, que restava impensável sob as condições da representação predominante - o povo, o trabalho, o proletariado -, que falha como referência real, que nem pertence ao ser nem ao dizer, que apresenta o contrário de uma narrativa fundadora. ${ }^{15}$

Todos nós somos comunistas, comunistas a meio-tempo. Com nossos filhos, amigos e amantes compartilhamos tudo de modo incondicionado, praticamos e exigimos igualdade, reciprocidade, compaixão e altruísmo. É só estender isso a todos para universalizar o melhor de nós. Basta isso, uma pequena revolução antropológica mais fácil do que preservar o regime do associalismo existente. "Que todos, de bom ou mau grado, saiam da caverna!" (BADIOU, 2012, p. 375). ${ }^{16}$

15 No decorrer dos séculos XIX e XX, a literatura promove de maneira igual a ideia do Eu desprovido de qualquer pertencimento ou particularidade; do herói do romance de formação que desenvolve e aperfeiçoa todos os seus talentos até o Homem sem qualidades, de Robert Musil.

16 "Que tout le monde, de gré ou de force, sorte de la caverne!"

Remate de Males, Campinas-SP, v. 37, n. 1, pp. 449-470, jan./jun. 2017 
E Platão? Mesmo no desastre siciliano há um epílogo sereno. Em 360 a.C., ele não rumou direto para Atenas. "Ao chegar a Olímpia, no Peloponeso, encontrei Dion entre os espectadores" (PLATÃO, 2011, p. 99). Tomaram assento na tribuna, a conversa andava para lá e para cá acerca da origem comum da democracia e da tragédia, o grand cru de Patmos do ano 373, da crise atual no oriente próximo, da dor e do sofrimento como negações mais antigas, sobre o "nem-rei nem-lei nem-opus-Dei" do filósofo e, por último, sobre a possibilidade de a filosofia se tornar disciplina olímpica, aberta a todos, de ingresso livre, para iniciar um novo jogo sem perdedores nem vencedores, possibilitando a todos devolver os seus bilhetes de entrada na caverna. Pouco antes do anoitecer, Platão, de repente preso de nostos, se recordando da sua formação musical quando jovem, toma a cítara e canta (versão traduzida):

\author{
With my feet on the sicilian air and my head \\ on the ground \\ I tried this trick and spin Dionísio round \\ His head will collapse \\ But there's nothing in it \\ And he will ask himself: \\ Where is my mind? \\ Where is my mind? \\ Where is my mind?
}

\title{
REFERÊNCIAS BIBLIOGRÁFICAS
}

ADORNO, Theodor W. Kulturkritik und Gesellschaft. In: Prismen. Frankfurt am Main: Suhrkamp, 1976.

ADORNO, Theodor W. Negative Dialektik. Frankfurt am Main: Suhrkamp, 1975.

ADORNO FICHTE, Johann Gottlieb. Die Bestimmung des Menschen. In: Fichtes sämtliche Werke. Vol. 2. Berlin: De Gruyter, 1965.

BADIOU, Alain. Conditions. London: Continuum, 2008.

BADIOU, Alain. La république de Platon. Paris: Fayard, 2012.

BADIOU, Alain. Logics of Worlds. London: Continuum, 2009.

BENN, Gottfried. Menschen Getroffen. In: . Destillationen. Neue Gedichte. Stuttgrat: Klett-Cotta, 1953. 
BLUMENBERG, Hans. Höhlenausgänge. Frankfurt am Main: Suhrkamp, 1989.

CASSIN, Barbara. L'effet sophistique. Paris: Gallimard, 1995.

DELEUZE, Gilles. A imagem-tempo. São Paulo: Brasiliense, 2007.

DELEUZE, Gilles. Diferença e repetição. Rio de Janeiro: Graal 2009.

FREUD, Sigmund. Das Ich und das Es. In: Gesammelte Werke. Vol. XIII. Frankfurt am Main: Fischer, 1972.

KANT, Immanuel. Was ist Aufklärung? Stuttgart: Reclam, 1986.

LACAN, Jacques. L'envers de la psychanalyse. Paris: Seuil, 1991.

LICHTENBERG, Georg Christoph. Sudelbücher II. In: . Werke in 6 Bänden. Frankfurt am Main: Suhrkamp, 1975.

NIETZSCHE, Friedrich. Götzendämmerung. Vol. 6. München/New York: Kritische Studienausgabe, 1980.

PLATÃO. A república. Trad. Maria Pereira. Lisboa: Calouste Gulbenkian, 1996.

PARMÊNIDES. Da natureza. Trad. José Trindade Santos. Brasília: Thesaurus, 2000.

THEUNISSEN, Michael. Negativität bei Adorno. In: Adorno-Konferenz 1983. Frankfurt am Main: Suhrkamp, 1983.

TÜRCKE, Christoph. Hyperaktiv! Kritik der Aufmerksamkeitsdezifitkultur. München: Beck, 2012.

WITTGENSTEIN, Ludwig. Tractatus logico-philosophicus. Stuttgart: Reclam, 2009, pp. 5-6.

\section{OBRAS CONSULTADAS}

BADIOU, Alain \& CASSIN, Barbara. Heidegger: o nazismo, as mulheres, a filosofia. Rio de Janeiro: Tinta Negra, 2011.

CASSIN, Barbara (ed.). Nos Grecs e leurs modernes: les stratégies contemporaines d'appropriation de l'Antiquité. Paris: Seuil, 1992.

BÍBLIA. A Bíblia de Jerusalém. Nova edição rev. e ampl. São Paulo: Paulus, 1985.

BLOCH, Ernst. Werkausgabe: Band 5: Das Prinzip Hoffnung. Frankfurt am Main: Suhrkamp, 1985. 
A volta de Siracusa: a negação platônica - 470

CHATELET, Francois. La naissance de l'histoire: la formation de la pensée historienne en Grèce. 2 vols. Paris: Minuit, 1961.

DIXSAUT, Monique (ed.). Contre-Platon. 2 vols. Paris: Vrin, 1993.

DROZ, Geneviève. Les mythes platoniciens. Paris: Points, 1992.

GADAMER, Hans-Georg. Platon und die Dichter. In: Gesammelte Werke. Vol. 6. Tübingen: Mohr Siebeck Verlag, pp. 197-211.

GAMM, Günther. Nicht nichts. Studien zu einer Semantik des Unbestimmten. Frankfurt am Main: Suhrkamp, 2000.

JOLY, Henri. Le renversement platonicien. Paris: Vrin, 1974.

VERNANT, Jean-Pierre. Les origines de la pensée grecque. Paris: PUF, 1962. 